\title{
Asupan Zat Gizi Makro dan Mikro terhadap Kejadian Stunting pada Balita
}

\author{
Ayuningtyas $^{1}$, Demsa Simbolon ${ }^{2}$, Ahmad Rizal $^{3}$ \\ 1,2,3 Jurusan Gizi, Politeknik Kementerian Kesehatan Bengkulu, Indonesia \\ Email: ayuningtyaszakaria05@gmail.com
}

\begin{abstract}
Macro and Micronutrient Substances intake Against Stunting in Toddlers. Stunting is a cumulative process and is caused by insufficient intake of nutrients or recurrent infectious diseases or both. Stunting can also occur before birth and is caused by very poor nutritional intake during pregnancy, eating patterns that are very lacking, low quality of food in line with the frequency of infectious diseases so that it can inhibit growth (UNICEF, 2012). This type of research was descriptive analytic. The study design was cross-sectional consisting of 58 samples of toddlers 24-59 months in the work area of Sumber Urip Health Center Rejang Lebong Regency in 2018. Data were collected in the form of nutritional status data TB/U using microtoice tools, energy intake, macro and micronutrients using questionnaires $2 \times 24$ hour recall. Toddlers 24 59 months who experienced stunting were 17 people $(29.3 \%)$ and normal ones were 41 people $(70.7 \%)$. The incidence of stunts was largely due to a lack of energy intake, and zinc. The results of this study indicate that there was a significant relationship between energy intake, macronutrients, and zinc with the incidence of stunting in infants.
\end{abstract}

Keywords: Energy intake, Macro and micro nutrient intake, Incidence of stunting

\begin{abstract}
Abstrak: Asupan Zat Gizi Makro dan Mikro terhadap Kejadian Stunting pada Balita. Stunting merupakan proses kumulatif dan disebabkan oleh asupan zat-zat gizi yang tidak cukup atau penyakit infeksi yang berulang, atau kedua-duanya. Stunting dapat juga terjadi sebelum kelahiran dan disebabkan oleh asupan gizi yang sangat kurang saat masa kehamilan, pola asuh makan yang sangat kurang, rendahnya kualitas makanan sejalan dengan frekuensi penyakit infeksi sehingga dapat menghambat pertumbuhan (UNICEF, 2012). Jenis penelitian adalah deskriptif analitik. Desain penelitian menggunakan cross sectional terdiri dari 58 sampel balita 24-59 bulan di wilayah kerja Puskesmas Sumber Urip Kabupaten Rejang Lebong Tahun 2018. Data yang dikumpulkan berupa data status gizi TB/U menggunakan alat microtoice, asupan energi, zat gizi makro dan mikro menggunakan kusioner recall $2 \times 24$ jam. Balita $24-59$ bulan yang mengalami stunting sebanyak 17 orang $(29,3 \%)$ dan yang normal sebanyak 41 orang $(70,7 \%)$. Kejadian stunting sebagian besar disebabkan oleh kurangnya asupan energi, zat gizi makro dan zink. Hasil penelitian ini menunjukkan ada hubungan yang signifikan antara asupan energi, zat gizi makro dan zink dengan kejadian stunting pada balita.
\end{abstract}

Kata kunci: Asupan energi, Asupan zat gizi makro dan mikro, Kejadian stunting

Global Nutrition Report tahun 2014 menunjukkan bahwa Indonesia termasuk dalam 17 negara dari 117 negara yang mempunyai tiga masalah gizi yaitu stunting, wasting dan overweight pada balita. (Kemenkes, 2016). Balita usia 24-59 bulan termasuk dalam golongan masyarakat kelompok rentan gizi (kelompok masyarakat yang paling mudah menderita kelainan gizi), sedangkan pada saat ini mereka sedang mengalami proses pertumbuhan yang relative pesat. Gangguan pertumbuhan linear, atau stunting, terjadi terutama dalam 2 sampai 3 tahun pertama kehidupan dan merupakan cerminan dari efek interaksi antara kurangnya asupan energi dan asupan gizi (Fitri, 2012).
Stunting merupakan masalah gizi kurang yang bersifat kronik pada masa pertumbuhan dan perkembangan,dengan nilai $z$-score tinggi badan menurut umur $(\mathrm{TB} / \mathrm{U})$ kurang dari -2 standar deviasi (SD) berdasarkan standar pertumbuhan (WHO, 2010). Stunting pada balita dapat menghambat perkembangan dan pertumbuhan dengan dampak negatif seperti penurunan intelektual, rentan terhadap penyakit tidak menular (Kemenkes RI, 2010).

Berdasarkan hasil Riset Kesehatan Dasar (Riskesdas) tahun 2013 terdapat 37,2\% balita yang mengalami stunting diantaranya $19,2 \%$ anak pendek dan 18,0\% sangat pendek. Prevalensi stunting tersebut mengalami 
peningkatan pada tahun 2010 yaitu sebesar $35,6 \%$.

Berdasarkan hasil Pemantauan Status Gizi (PSG) di provinsi Bengkulu prevalensi stunting sebesar $16 \%$ dan Kabupaten Rejang Lebong prevalensi stunting pada tahun 2016 sebesar $27,9 \%$ diantaranya $12,7 \%$ balita sangat pendek dan $22,6 \%$ balita pendek.

Hal ini menandakan bahwa masalah stunting pada balita merupakan masalah kesehatan masyarakat. Masalah kesehatan masyarakat ini dianggap berat bila prevalensi pendek sebesar 30-39\% dan dianggap serius bila prevalensi pendek sebesar $\geq 40 \%$ (Depkes RI, 2013). Prevalensi Stunting tersebut lebih tinggi dibandingkan dengan angka prevalensi berat kurang (underweight) yaitu 19,6\%, balita kurus $12,1 \%$.

\section{METODE}

Jenis penelitian kuantitatif dengan pendekatan cross sectional. Variabel independen asupan zat gizi makro dan mikro, variabel dependen kejadian stunting. Menggunakan uji chi square pada 58 balita usia 24-59 bulan di wilayah kerja Puskesmas Sumber Urip Kabupaten Rejang. Status gizi balita diperoleh dari z-score TB/U menggunakan WHO Anthro dan asupan zat gizi makro dan mikro diperoleh dari form recall $2 \times 24$ jam. Analisis data menggunakan komputer (SPSS).

\section{HASIL}

Tabel 1. Gambaran Kejadian Stunting

\begin{tabular}{lcc}
\hline Kejadian Stunting & $\mathbf{n}$ & $\mathbf{\%}$ \\
\hline Ya & 17 & 29,3 \\
Tidak & 41 & 70,7 \\
\hline Total & 58 & 100 \\
\hline
\end{tabular}

Berdasarkan tabel 1 didapatkan hasil balita 24-59 bulan yang mengalami stunting sebanyak 17 orang $(29,3 \%)$ dan yang normal sebanyak 41 orang $(70,7 \%)$. Hal ini merupakan masalah kesehatan masyarakat yang dianggap berat karena prevalensi stunting lebih dari $20 \%$. Berdasarkan hasil pemantauan status gizi di provinsi Bengkulu tahun 2016 prevalensi stunting di provinsi Bengkulu sebesar 16\%. Menurut hasil penelitian di Wilayah Kerja Puskesmas Sumber Urip Kabupaten Rejang Lebong memiliki persentase stunting yang tinggi yaitu 29,3\% dibandingkan dengan provinsi Bengkulu.
Tabel 2. Gambaran Aupan Zat Gizi Makro

\begin{tabular}{lcccccc}
\multirow{2}{*}{ Zat Makro } & \multicolumn{2}{c}{ Kurang } & \multicolumn{2}{c}{ Cukup } & \multicolumn{2}{c}{ Total } \\
\cline { 2 - 7 } & n & $\mathbf{\%}$ & n & \% & n & \% \\
\hline Energi (gr) & 21 & 36,2 & 37 & 63,8 & 58 & 100 \\
\hline Protein (gr) & 34 & 58,6 & 24 & 41,4 & 58 & 100 \\
\hline Lemak (gr) & 30 & 51,7 & 28 & 48,3 & 58 & 100 \\
\hline Karbohidrat (gr) & 22 & 37,9 & 36 & 62,1 & 58 & 100 \\
\hline
\end{tabular}

Berdasarkan tabel 2 asupan protein (41.4\%), lemak (48.3\%) cenderung kurang sedangkan asupan energi (63.8\%) dan karbohidrat $(62.1 \%)$ cukup.

Tabel 3. Gambaran Asupan Zat Gizi Mikro

\begin{tabular}{lcccccc}
\hline \multirow{2}{*}{ Zat Mikro } & \multicolumn{2}{c}{ Kurang } & \multicolumn{2}{c}{ Cukup } & \multicolumn{2}{c}{ Total } \\
\cline { 2 - 7 } & n & \% & n & \% & n & \% \\
\hline Zink (gr) & 31 & 53,4 & 27 & 46,6 & 58 & 100 \\
Vit D (gr) & 33 & 56,9 & 25 & 43,1 & 58 & 100 \\
Fe (gr) & 45 & 77,6 & 13 & 22,4 & 58 & 100 \\
\hline
\end{tabular}

Berdasarkan tabel 3 didapatkan hasil bahwa asupan zat gizi mikro lebih cenderung kurang yaitu asupan zink $(53,4 \%)$ dan asupan vitamin D kurang $(56,9 \%)$, asupan Fe kurang $(77,6 \%)$,

Tabel 4. Hubungan Asupan Zat Gizi Makro Dengan Kejadian Stunting

\begin{tabular}{lccccccc}
\hline \multirow{2}{*}{$\begin{array}{c}\text { Asupan } \\
\text { Energi }\end{array}$} & \multicolumn{4}{c}{ Kejadian Stunting } & \multicolumn{2}{c}{ Total } & \multirow{2}{*}{$\boldsymbol{p}$ - } \\
\cline { 2 - 5 } & \multicolumn{2}{c}{ Ya } & \multicolumn{2}{c}{ Tidak } & \multirow{2}{*}{ n } & \% & value \\
\hline Kurang & 12 & 57,1 & 9 & 42,9 & 21 & 100 & \\
Cukup & 5 & 13,5 & 32 & 86,5 & 37 & 100 & 0,001 \\
Total & 17 & 29,3 & 41 & 100 & 58 & 100 & \\
\hline
\end{tabular}

\begin{tabular}{lccccccc}
\hline \multicolumn{2}{l}{ Asupan Protein } & & & & & & \\
\hline Kurang & 15 & 44,1 & 19 & 55,9 & 34 & 100 & \\
Cukup & 2 & 8,3 & 22 & 91,7 & 24 & 100 & 0,008 \\
Jumlah & 17 & 29,3 & 41 & 70,7 & 58 & 100 & \\
\hline \multicolumn{4}{l}{ Asupan Lemak } \\
\hline Kurang & 14 & 46,7 & 16 & 53,3 & 30 & 100 & \\
Cukup & 3 & 10,7 & 25 & 89,3 & 28 & 100 & 0,007 \\
Jumlah & 17 & 29,3 & 41 & 70,7 & 58 & 100 & \\
\hline
\end{tabular}

Asupan Karbohidrat

\begin{tabular}{lllllll}
\hline Kurang & 12 & 54,5 & 10 & 45,5 & 22 & 100
\end{tabular}

$\begin{array}{lllllll}\text { Cukup } & 5 & 13,9 & 31 & 86,1 & 36 & 100\end{array}$

$\begin{array}{llllllll}\text { Jumlah } & 17 & 29,3 & 41 & 70,7 & 58 & 100 & 0,003\end{array}$

Tabel 4 menunjukkan hasil analisis hubungan antara asupan energi dengan kejadian stunting pada balita diperoleh bahwa asupan energi yang kurang sebagian besar mempengaruhi kejadian stunting sebanyak $57,1 \%$. Hasil uji statistik di dapatkan p-value 0,001 , artinya ada hubungan yang signifikan antara tingkat asupan energy dengan kejadian stunting, dari hasil analisis terdapat hubungan antara asupan protein dengan kejadian stunting pada balita diperoleh bahwa sebagian besar asupan protein kurang pada balita stunting sebesar $44,1 \%$ dan asupan protein yang cukup 
pada balita stunting sebesar 8,3\%. Hasil uji statistic didapatkan p-value 0.008 , berarti ada hubungan yang signifikan antara tingkat asupan protein dengan kejadian stunting. Hubungan asupan lemak dengan kejadian stunting menunjukkan hasil ada hubungan antara asupan lemak dengan kejadian stunting pada balita diperoleh bahwa asupan lemak kurang pada balita stunting sebesar $46,7 \%$ dan asupan lemak yang cukup pada balita stunting sebesar $10,7 \%$. Hasil uji statistic didapatkan p-value 0.007, berarti ada hubungan yang signifikan antara tingkat asupan lemak dengan kejadian stunting. Dari hasil analisis hubungan antara asupan karbohidrat dengan kejadian stunting pada balita diperoleh bahwa sebagian besar asupan karbohidrat kurang sebesar $54,5 \%$ dan asupan karbohidrat cukup pada balita stunting sebesar 13,9\%. Di dapatkan hasil uji statistik p-value 0,003 , berarti ada hubungan yang signifikan antara tingkat asupan karbohidrat dengan kejadian stunting.

Tabel 5. Hubungan Asupan Zat Gizi Mikro dengan Kejadian Stunting

\begin{tabular}{|c|c|c|c|c|c|c|c|}
\hline \multirow{3}{*}{$\begin{array}{c}\text { Asupan } \\
\text { Zink }\end{array}$} & \multicolumn{4}{|c|}{ Kejadian Stunting } & \multicolumn{2}{|c|}{ Total } & \multirow{3}{*}{$\underset{\text { value }}{p-}$} \\
\hline & \multicolumn{2}{|c|}{$\mathbf{Y a}$} & \multicolumn{2}{|c|}{ Tidak } & & \multirow{2}{*}{$\%$} & \\
\hline & $\mathbf{n}$ & $\%$ & $\mathbf{n}$ & $\%$ & & & \\
\hline Kurang & 14 & 45,2 & 17 & 54,8 & 31 & 100 & \\
\hline $\mathrm{Cl}$ & 3 & 11,1 & 24 & 88,9 & 27 & 100 & 0,011 \\
\hline & 17 & 29,3 & 41 & 70,7 & 58 & 100 & \\
\hline \multirow{3}{*}{$\begin{array}{c}\text { Asupan } \\
\text { Vit D }\end{array}$} & \multicolumn{4}{|c|}{ Kejadian Stunting } & \multicolumn{2}{|c|}{ Total } & \multirow{3}{*}{$\begin{array}{c}p- \\
\text { value }\end{array}$} \\
\hline & \multicolumn{2}{|c|}{ Ya } & \multicolumn{2}{|c|}{ Tidak } & \multirow[b]{2}{*}{ n } & \multirow{2}{*}{$\%$} & \\
\hline & $\mathbf{n}$ & $\%$ & $\mathbf{n}$ & $\%$ & & & \\
\hline Kurang & 10 & 30,3 & 23 & 69,7 & 33 & 100 & \\
\hline $\mathrm{C}$ & 7 & 28,0 & 18 & 72,0 & 25 & 100 & 1,000 \\
\hline imlal & 17 & 29,3 & 41 & 70,7 & 58 & 100 & \\
\hline \multirow{3}{*}{$\begin{array}{c}\text { Asupan } \\
\text { Fe }\end{array}$} & \multicolumn{4}{|c|}{ Kejadian Stunting } & \multicolumn{2}{|c|}{ Total } & \multirow{3}{*}{$\begin{array}{c}p- \\
\text { value }\end{array}$} \\
\hline & \multicolumn{2}{|c|}{ Ya } & \multicolumn{2}{|c|}{ Tidak } & & \multirow{2}{*}{$\%$} & \\
\hline & $\mathbf{n}$ & $\%$ & $\mathbf{n}$ & $\%$ & & & \\
\hline Kuran & 15 & 33,3 & 30 & 66,7 & 45 & 100 & \\
\hline Cukup & 2 & 15,4 & 11 & 84,6 & 13 & 100 & 0,365 \\
\hline Jumlah & 17 & 29,3 & 41 & 70,7 & 58 & 100 & \\
\hline
\end{tabular}

Tabel 5 menunjukkan hasil analisis hubungan antara asupan zink dengan kejadian stunting pada balita diperoleh bahwa pada balita stunting asupan zink kurang sebesar 45,2\% dan asupan zink cukup pada balita stunting sebesar $11,1 \%$. Hasil uji statistik didapatkan $p$-value 0.011 , berarti ada hubungan yang signifikan antara tingkat asupan zink dengan kejadian stunting. Dari hasil analisis hubungan antara asupan vitamin D dengan kejadian stunting pada balita diperoleh bahwa asupan vitamin D kurang pada balita stunting sebesar 30,3\% dan asupan vitamin D cukup pada balita stunting sebesar $28,0 \%$. Hasil uji statistik didapatkan p-value
1,000 , berarti tidak ada hubungan yang signifikan antara tingkat asupan vitamin D dengan kejadian stunting. Tidak ada hubungan antara asupan $\mathrm{Fe}$ dengan kejadian stunting pada balita diperoleh bahwa asupan Fe kurang pada balita stunting sebesar 33,3\% dan asupan Fe yang cukup pada balita stunting sebesar $15,4 \%$. Hasil uji statistik di dapatkan $p$-value 0,365 , berarti tidak ada hubungan yang signifikan antara tingkat asupan $\mathrm{Fe}$ dengan kejadian stunting. Hasil analisis asupan kalsium tidak ada hubungan

\section{PEMBAHASAN}

\section{Hubungan Asupan Energi Dengan Kejadian Stunting}

Hasil penelitian ini menunjukkan ada hubungan yang signifikan antara asupan energi dengan kejadian stunting pada balita ditunjukkan dengan nilai $p=0,001(\mathrm{p}<0.05)$.

Hasil penelitian sejalan dengan penelitian Oktarina (2013) yang menunjukkan bahwa terdapat hubungan antara tingkat asupan energi dengan kejadian stunting pada balita. Hal ini disebabkan karena tingkat asupan energi yang diperoleh pada penelitian ini hanya menggambarkan keadaan asupan balita sekarang, sementara status gizi stunting merupakan akumulasi dari kebiasaan makan terdahulu, sehingga asupan hanya pada hari tertentu tidak dapat langsung mempengaruhi status gizi.

Rendahnya asupan energi pada balita stunting kemungkinan disebabkan oleh beberapa faktor diantaranya frekuensi dan jumlah pemberian makan, nafsu makan balita berkurang, densitas energi yang rendah, dan ada penyakit infeksi penyerta. Kejadian stunting merupakan peristiwa yang terjadi dalam periode waktu yang lama.

Asupan energi yang tidak mencukupi kebutuhan dapat menyebabkan terjadinya ketidakseimbangan energi. Ketidakseimbangan energi secara berkepanjangan menyebabkan terjadinya masalah gizi. Balita dengan tingkat asupan energi yang rendah mempengaruhi pada fungsi dan struktural perkembangan otak serta dapat mengakibatkan pertumbuhan dan perkembangan kognitif yang terhambat. Energi yang berasal dari makanan dapat diperoleh dari beberapa zat gizi makro yaitu karbohidrat, protein dan lemak. Energi memiliki fungsi sebagai penunjang proses pertumbuhan, metabolisme tubuh dan berperan dalam proses aktivitas fisik. 
Hubungan Asupan Protein dengan Kejadian Stunting

Berdasarkan uji statistik terdapat hubungan antara asupan protein dengan kejadian stunting pada balita usia $24-59$ bulan diperoleh nilai $\mathrm{p}$ $0,008(p<0,05)$.

Penelitian ini sejalan dengan penelitian yang dilakukan Aridiyah (2015) analisis hubungan tingkat kecukupan protein dengan kejadian stunting pada anak balita menunjukkan bahwa tingkat kecukupan protein di daerah pedesaan berhubungan dengan kejadian stunting pada anak balita. Hal ini sesuai dengan penelitian Aridiyah (2015), yang menunjukkan bahwa asupan protein berhubungan dengan stunting.

Protein merupakan zat gizi yang diperlukan oleh tubuh untuk pertumbuhan, membangun struktur tubuh (otot, kulit, dan tulang) serta sebagai pengganti jaringan yang sudah usang (Almatsier, 2005). Protein merupakan salah satu zat gizi makro yang berfungsi sebagai zat pembangun, pemelihara sel dan jaringan tubuh serta membantu dalam metabolisme sistem kekebalan tubuh seseorang.

\section{Hubungan Asupan Lemak dengan Kejadian Stunting}

Hasil penelitian ini menunjukkan ada hubungan yang signifikan antara asupan lemak dengan kejadian stunting pada balita ditunjukkan dengan nilai $p=0.007(p<0,05)$

Penelitian ini sejalan dengan penelitian Oktarina Zilda (2013) yang menunjukkan bahwa balita dengan tingkat asupan lemak yang rendah mengalami stunting lebih banyak dibandingkan balita dengan asupan lemak cukup, hasil penelitian menunjukkan terdapat hubungan antara asupan lemak dengan kejadian stunting pada balita. Balita dengan tingkat asupan lemak rendah berisiko mengalami stunting dibandingkan balita dengan tingkat asupan lemak cukup.

Survei yang dilakukan di Cina pada tahun 2006 menunjukkan kejadian stunting pada anak usia kurang dari lima tahun dikaitkan dengan asupan energi, protein, dan lemak (Xiaoli, 2009).

\section{Hubungan Asupan Karbohidrat dengan Kejadian Stunting}

Berdasarkan uji statistik terdapat hubungan antara asupan karbohidrat dengan kejadian stunting diperoleh nilai $p=0,003(p<0,05)$.

Penelitian ini sejalan dengan hasil penelitian Oktarina (2013) analisis hubungan tingkat konsumsi karbohidrat dengan kejadian stunting, didapatkan bahwa 47,2\% balita dengan konsumsi karbohidrat rendah mengalami stunting. Diantara balita dengan tingkat konsumsi karbohidrat cukup sebanyak 41,3\%.

Konsumsi karbohidrat lebih banyak dikonsumsi karena sesuai dengan teori yang mengatakan bahwa karbohidrat merupakan penyedian energi utama dan sumber makanan yang relatif lebih murah dibanding dengan zat gizi lain (Almatsier, 2009).

\section{Hubungan Asupan Zink dengan Kejadian Stunting}

Hasil penelitian ini menunjukkan ada hubungan yang signifikan antara asupan zink dengan kejadian stunting ditunjukkan dengan nilai $p=0.011(p<0,05)$.

Hasil penelitian ini sesuai dengan penelitian Anindita (2012) yang menyatakan bahwa zink memiliki fungsi yang sangat esensial meski tubuh hanya membutuhkan dalam jumlah sedikit. Jumlah kebutuhan yang sangat sedikit tidak dapat diakomodasikan oleh tubuh sendiri. Tubuh membutuhkan asupan zink berdasarkan makanan yang kita konsumsi setiap hari. Kelompok yang paling beresiko terhadap kekurangan zink adalah balita yang masih berada pada masa pertumbuhan karena sangat berpengaruh terhadap pertumbuhan tinggi badan (Almatsier, 2005).

Balita kurang asupan zink, dapat berdampak balita menjadi malas makan. Nafsu makan balita berkurang sehingga berakibat pada berkurangnya seluruh asupan zat nutrisi yang lain. Pada beberapa penelitian dikatakan bahwa kekurangan zink akan berakibat pada gangguan pertumbuhan pada balita akan mengalami perasaan tidak enak di perut, lambung akan terganggu, mual, gelisah, pusing dan diare (Tatar, 2009).

\section{Hubungan Asupan Vitamin D dengan Kejadian Stunting}

Hasil penelitian ini menunjukkan tidak ada hubungan yang signifikan antara asupan Vitamin $\mathrm{D}$ dengan kejadian stunting ditunjukkan dengan nilai $p=0,811(p<0,05)$

Tidak adanya hubungan pada penilitian ini dikarenakan sumber vitamin hanya didapatkan dari segi makanan nya saja sedangkan sumber vitamin $\mathrm{D}$ juga terdapat dari paparan sinar matahari pagi. Dalam penelitian ini tidak diukur secara detail berapa lama paparan sinar matahari yang didapatkan balita. 


\section{Hubungan Asupan Fe dengan Kejadian Stunting}

Hasil penelitian ini menunjukkan tidak ada hubungan yang signifikan antara asupan $\mathrm{Fe}$ dengan kejadian stunting ditunjukkan dengan nilai $p=0,365(\mathrm{p}<0,05)$.

Hasil penelitian ini sejalan dengan penelitian Astutik (2018), yang menunjukkan bahwa tidak ada hubungan antara asupan zat besi dengan kejadian stunting pada balita dan asupan zat besi bukan merupakan faktor risiko terjadinya stunting pada masa balita. Penelitian ini sejalan dengan penelitian yang dilakukan Priyono Dicka Indo Putri (2015) di Kabupaten Lumajang yang menyatakan bahwa tidak terdapat hubungan antara asupan zat besi dengan kejadian stunting. Selain berdampak anemia gizi besi, kekurangan zat besi juga berdampak menurunkan kemampuan imunitas tubuh, sehingga penyakit infeksi mudah masuk ke dalam tubuh. Anemia besi dan penyakit infeksi yang berkepanjangan akan berdampak pada pertumbuhan linier anak (Damayanti, 2016).

\section{DAFTAR PUSTAKA}

Almatsier, Sunita. 2005. Prinsip Dasar Ilmu Gizi. Jakarta: Gramedia Pustaka Utama.

Almatsier, Sunita. 2009. Prinsip Dasar Ilmu Gizi. Jakatra:Gramedia Pustaka Utama.

Anindita, Putri. 2012. Hubungan Tingkat Pendidikan Ibu, Pendapatan Keluarga, Kecukupan Protein \& Zinc Dengan Stunting (Pendek) Pada Balita Usia 6- 935 Bulan di Kecamatan Tembalang Kota Semarang. Jurnal Kesehatan Masyarakat, 1(2), pp.617-26

Aridiyah, F. O., Rohmawati, N., \& Ririanty, M. 2015. Faktor-faktor yang Mempengaruhi Kejadian Stunting pada Anak Balita di Wilayah Pedesaan dan Perkotaan (The Factors Affecting Stunting on Toddlers in Rural and Urban Areas). Pustaka Kesehatan, 3(1), 163-170.

Astutik, A., Rahfiludin, M. Z., \& Aruben, R. 2018. Faktor Risiko Kejadian Stunting Pada Anak Balita Usia 24-59 Bulan (Studi Kasus di Wilayah Kerja Puskesmas Gabus II Kabupaten Pati Tahun 2017). Jurnal Kesehatan Masyarakat (e-Journal), 6(1), 409-418.

Damayanti RA, Muniroh L, Farapti. 2016. Perbedaan Tingkat Kecukupan Zat Gizi dan Riwayat Pemberian AS. Media Gizi

\section{SIMPULAN}

Berdasarkan hasil penelitian yang telah dilakukan maka dapat disimpulkan sebagai berikut :

1. Kurangnya asupan protein, lemak, vitamin D dan Fe menyebabkan terjadinya stunting. Didapatkan hasil $29,3 \%$ balita yang mengalami kejadian stunting.

2. Terdapat hubungan antara zat gizi makro, zink dengan kejadian stunting pada balita.

3. Tidak ada hubungan antara asupan vitamin D, Fe dengan kejadian stunting pada balita.

\section{SARAN}

Banyak variabel yang tidak diteliti seperti umur dan pendidikan diharapkan adanya penelitian lebih lanjut pada variabel yang berbeda.

Perlunya pemantauan pertumbuhan balita seperti melakukan pengukuran tinggi badan secara teratur melalui posyandu.

Indonesia, Vol. 11, No. 1 Januari-Juni: hlm. 61-69.

Depkes RI. 2013. Riskesdas 2013. Depkes RI. Jakarta

Depkes RI. 2016. Penilaian Status Gizi 2016. Dinas Kesehatan Provinsi Bengkulu.

Fitri. 2012. Berat Lahir Sebagai Faktor Dominan Terjadinya Stunting pada Balita (12-59 bulan) di Sumatera (Analisis data riskesdas 2010). [Skripsi], Depok: Fakultas Ilmu Kesehatan Masyarakat, Universitas Indonesia.

Kementerian Kesehatan RI. 2016. Infodatin Situasi Balita Pendek.

http://www.depkes.go.id/resou

rces/download/pusdatin/infoda tin/situasibalita-pendek2016.pdf.

Kementerian Kesehatan RI. 2010. Standar Amtropometri Penialian Status Gizi Anak. Jakarta: Direktorat Bina Gizi dan Kesehatan Ibu dan Anak.

Oktarina Zilda dan Trini Sudiarti. 2013. Faktor Risiko Stunting Pada Balita (24-59 Bulan) di Sumatera. Jurnal Gizi dan Pangan, November 2013, 8(3): 175-180

Priyono Dicka Indo Putri, dkk. 2015. Determinan Kejadian Stunting pada Anak Balita Usia 12-36 Bulan di Wilayah Kerja Puskesmas 
Randuagung Kabupaten Lumajang. Jurnal Gizi Kesehatan Masyarakat, Fakultas Kesehatan Masyarakat Universitas Jember. e-Jurnal Pustaka Kesehatan, vol. 3 (no. 2) Mei

Tatar. 2009. Hubungan Seng Plasma Dengan Status Gizi. Jurnal Departemen Gizi, Volume 16 Nomor 5 Tahun 2009.
UNICEF, 2012. Ringkasan Kajian Gizi Oktober 2012. Jakarta: UNICEF Indonesia

WHO. 2010. The World Health Report 2010.

Xiaoli W, Beng H, \& Sufang G et al. 2009. Stunting and overweight in the WHO child growth standard: malnutrition among children in poor area in China. Public Health Nutrition, 12(11), 1991-1998. 